\title{
SIGNIFICANCE OF EDUCATION FOR THE ECONOMY OF SUSTAINABLE DEVELOPMENT - TOWARD SOCIAL RESPONSIBILITY
}

\author{
BEATA SADOWSKA \\ University of Szczecin, Faculty of Management and Economics of Services, POLAND \\ e-mail: beata.sadowska@wzieu.pl
}

RECEIVED
ACCEPTED
JEL
CLASSIFICATION

KEYWORDS

ABSTRACT

\author{
20 April 2018 \\ 12 July 2018 \\ A20, Q01
}

education, sustainable development, social responsibility, environment

In Poland, children and teenagers are obligatorily subject to the process of mainstream education until a particular age, currently until lower secondary schools, which are being closed. Some children and teenagers continue their education in upper secondary schools and some study at universities. The mission of education is to achieve diverse knowledge of life and the surrounding world. One of the elements of primary and further education is promoting knowledge of the natural environment, natural resources, plants, animals and the role of ecosystems in the life of every human being and economic entity. The objective of the study is to determine the role and significance of education and to indicate effects of education on sustainable development in the context of creating individual social responsibility for the natural environment.

A fundamental hypothesis is as follows: "Long-term educational programmes executed as part of the education system and activities of enterprises, organizations, foundations or associations considerably contribute to the development of a high level of natural and ecological awareness of the young generation". The following methods and exploration techniques were used in the research process: desk research, critical analysis of national and foreign literature on the subject, structured interview (standardized). The research was conducted among students of Finance and Accounting of the University of Szczecin and will be finished on 10 October 2017. The research findings will enable formulating conclusions and recommendations.

\section{Introduction}

One of the elements of primary and further education is promoting knowledge of the natural environment, natural resources, plants, animals and the role of ecosystems in the life of every human being and economic entity.

The objective of the study is to determine the role and significance of education and to indicate effects of education on sustainable development in the context of creating individual social responsibility for the natural 
environment. A fundamental hypothesis is as follows: "Long-term educational programmes executed as part of the education system and activities of enterprises, organizations, foundations or associations considerably contribute to developing a high level of natural and ecological awareness of the young generation". The following methods and exploration techniques were used in the research process: desk research, critical analysis of national and foreign literature on the subject, structured interview (standardized). The research was conducted among students of Finance and Accounting of the University of Szczecin. The research findings enabled formulating conclusions and recommendations.

\section{Sustainable development - precursors, definitions, objectives}

In the second half of the 20th century, the concept of sustainable development influenced perceiving mutual relations between economy, society and natural resources. Sustainable development is long-term development carried out by society and business entities. The term sustainable development was used for the first time at the Conference in Stockholm in 1972 when tasks and goals of global environmental protection were discussed. ${ }^{1}$ The transfer of this concept to international documents took place at the 2nd Conference of the United Nations on Environment and Development in Rio de Janeiro in June 1992. One of important documents is Agenda 21. Sustainable development is not an univocal term. Authors interpret it variously, however, a common feature of these definitions is some kind of a desirable condition which is economically justified and economically and socially acceptable. Views of researchers and thinkers who have had an influence on the codification of the concept of sustainable development are presented in Table 1.

Table 1. Precursors of the concept of sustainable development

\begin{tabular}{|c|c|c|}
\hline No. & Specification & Description \\
\hline 1 & 2 & 3 \\
\hline 1. & $\begin{array}{l}\text { Physiocrats, 18th century } \\
\text { - Quesnay }\end{array}$ & $\begin{array}{l}\text { - they assumed that the only source of all wealth was land, } \\
\text { - natural resources are necessary factors of production }\end{array}$ \\
\hline 2. & T. Maltus, $1766-1834$ & - sustainable development is not possible without limiting population growth \\
\hline 3. & J.S. Mill, $1806-1873$ & $\begin{array}{l}\text { - competitive economy based on responsibility for the common good, } \\
\text { - biodiversity is important, } \\
\text { - steady-state economy }\end{array}$ \\
\hline 4. & K. Darwin, 1809-1882 & - justice and decent life for all people \\
\hline 5. & K. Marx, 1818-1883 & $\begin{array}{l}\text { - analyses of social development conditions with regard to economic development, } \\
\text { - risk connected with human exploitation, } \\
\text { - economic development versus individual interests of economic actors }\end{array}$ \\
\hline 6. & E. Haeckel, 1834-1919 & $\begin{array}{l}\text { - he used the word ecology for the first time in } 1866, \\
\text { - ecology is economics of nature, } \\
\text { - the discipline of ecology derived from biology and ethology and at the beginning it became a field of economics } \\
\text { dealing with non-human part of nature }\end{array}$ \\
\hline 7. & A. Pigou, 1877-1957 & $\begin{array}{l}\text { - conclusion on the optimal division of goods by the market, } \\
\text { - the market is unreliable, } \\
\text { - producers and consumers transfer a part of social costs in the form of external effects onto third parties } \\
\text { (e.g. society), } \\
\text { - the internalization of external effects through fees, taxes - economic instruments of environmental protection, } \\
\text { - natural resources - the public good }\end{array}$ \\
\hline
\end{tabular}

${ }^{1}$ More on the concept of financing activities related to environmental protection from EU funds on the regional level: Kogut-Jaworska (2018), pp. 411-415. 


\begin{tabular}{rll}
\hline 1 & \multicolumn{1}{c}{2} & \multicolumn{1}{c}{3} \\
\hline 8. & J.M. Keynes, 1883-1946 & $\begin{array}{l}\text { - the author of the theoretical underpinning for social and ecological market economy or mixed economy } \\
\text { in which the state takes responsibility in case of unreliability of the market }\end{array}$ \\
\hline 9. & $\begin{array}{l}\text { N. Georgescu-Roegen, } \\
\text { 1906-1994 }\end{array}$ & $\begin{array}{l}\text { - "the father of ecological economics" - he came to the conclusion that energy is used during all economic } \\
\text { processes }\end{array}$ \\
\hline 10. & K.W. Kapp, 1910-1976 & $\begin{array}{l}\text { - he dealt with the issues of threats to the natural environment, } \\
\text { - he refined the theory of the externalization of social costs during production }\end{array}$ \\
\hline 11. & $\begin{array}{l}\text { A. Sen, born in 1933 } \\
\text { Nobel Prize in 1998 }\end{array}$ & $\begin{array}{l}\text { - he created a new theory of freedom and poverty, } \\
\text { - he emphasised the significance of the sociocultural dimension in sustainable development }\end{array}$ \\
\hline
\end{tabular}

Source: own work on the basis of Rogall (2010), pp. 118-124.

I. Sasch defines sustainable development as "development aiming at harmonising (reasonable management) various goals: economic, social and ecological ones". Whereas Hopfer indicates that "sustainable development is conducting business activity in harmony with the natural environment in such a way that no irreversible changes are caused" (Pionek, 2002). Sustainable development is "development aiming at harmonising various goals: economic, social, ecological, political and cultural ones". It is "conducting business activity in harmony with the natural environment in such a way that no irreversible changes are caused" (Sadowska, 2016). One should agree with Rogall (2010) that sustainable development is development which satisfies current needs of citizens without risk that future generations will not be able to satisfy their needs. Sustainable development ${ }^{2}$ ensures that all humans have high ecological, economic and sociocultural standards.

An important achievement of current activities for sustainable development is the acknowledgement of the significance of the environmental dimension for ensuring the growth of potential in the world and creating proper living conditions for present and future generations. Effective management of natural resources involves mainly environmental activities guaranteeing sustainable development. Key objectives of sustainable development include: ${ }^{3}$

1. Eliminating poverty in all its forms around the world, eliminating hunger, achieving food security and better nutrition standards as well as promoting sustainable farming.

2. Guaranteeing all people at every age a healthy lifestyle and promoting prosperity as well as ensuring highquality education and promoting life-long learning.

3. Ensuring that all people have access to water and sanitation through sustainable management of water resources, developing stable infrastructure, promoting sustainable industrialisation and supporting innovation.

4. Protecting, restoring and promoting sustainable use of terrestrial ecosystems, sustainable forest management, preventing and reversing the process of soil degradation.

It should be highlighted that sustainable development is not substitution development, i.e. improving one part of the natural environment at the cost of damaging the other part. It is the development of all parts of economy in a way which does not threaten environmental goods, and the key task of education is to propagate knowledge about goals, functions and effects of activities for sustainable development.

2 More on the concept of sustainable development: Pearce, Turner (1990). Economics of natural resources and the environment, Harvester Wheatsheaf, New York, after: Woś (1992); Hauff (1987), p. 46; Luks (2002), p. 20; Radke (2001), p. 72.

${ }^{3}$ See http://www.gridw.pl/cele-zrownowazonego-rozwoju (1.10. 2017). 


\section{Objectives, tasks and fields of the implementation of education for the economy of sustainable development - theoretical aspects}

Every human is personally accountable for implementing sustainable development. One should agree with M. Wójcik-Jurkiewicz (2016) that responsibility of business entities concerns identifying and acknowledging the combination of connections of all values and standards creating a business institution in the social and natural environment in which it operates and without which it could not operate. Through their everyday activities, people and organizations directly and indirectly contribute to the implementation of, or failure to implement, the concept of sustainable development. Since the earliest years, a human is provided with knowledge of the role and significance of the natural environment.

Nowadays, knowledge is considered to be the most valuable asset and improving education for sustainable development becomes more and more important. According to the author, education for sustainable development should:

- raise social awareness in terms of the protection of natural resources and biodiversity as well as guarantee full access to information on using the natural environment,

- enable each society member to acquire knowledge, qualifications, competence and skills necessary to improve the condition of the natural environment,

- create new attitudes and models of consumer behaviour which will take account of care of the quality of the natural environment, non-renewable resources and will result in consumers' and producers' conscious decisions.

One should agree with T. Borys (2010) that an important document concerning education for sustainable development is the United Nations Strategy adopted at a high-level meeting of representatives of the Ministries of the Environment and Education (Vilnius, 17-18 March 2005). This Strategy indicates the need to extend knowledge and educate society taking account of the complexity of problems regarding environmental management, and postulates:

- pursuing balance between the social and economic good, culture, ecology, tradition, policy and respect for biodiversity,

- raising awareness of the value of equality, justice, social harmony and mutual respect,

- ensuring that each individual has the possibility of social education, and during the process of education instilling values without which sustainable development in terms of social and ecological dimensions would not be possible.

As E. Lorek and A. Sobol (2010) point out, in terms of teaching techniques, education for sustainable development is most often connected with ecological education. Among other things, it is visible in a government document, the National Strategy for Ecological Education - through education to sustainable development, in which such terms as ecological education, environmental education and education for sustainable development are used interchangeably.

Objectives that education for sustainable development should execute, in accordance with the provisions of the National Strategy for Ecological Education, are presented in Figure 1. 
Raising full social awareness and interest through mutually connected ecological, social, political and cultural issues
Enabling each person to acquire knowledge, competence and skills necessary to improve the condition of the natural environment
Creating new models of behaviour, attitudes, values and beliefs of individuals, groups and societies, taking account of care of the quality of natural resources (personal responsibility, ethical behaviour)

Figure 1. Objectives of education for sustainable development

Source: own work on the basis of: National Strategy... (2001).

Organization of ecological education in the official education system in Poland is presented in Table 2.

Table 2. Organization of ecological education in the official education system in Poland

\begin{tabular}{|c|c|c|c|}
\hline $\begin{array}{c}\text { Education } \\
\text { level }\end{array}$ & Stage & Specification & Execution of objectives: \\
\hline 1 & $\begin{array}{l}\text { Preschool } \\
\text { education }\end{array}$ & $\begin{array}{l}\text { The goal of preschool education in terms of raising } \\
\text { ecological awareness is: } \\
\text { 1. Stimulating willingness and developing skills to observe } \\
\text { the natural environment. } \\
\text { 2. Developin sensitivity to both the beauty and destruction } \\
\text { of the environment. } \\
\text { 3. Teaching respect for other beings. } \\
\text { 4. Influencing parents' lifestyle and ecological awareness. } \\
\text { 5. Building pro-ecological habits and behaviours in one's } \\
\text { everyday life }\end{array}$ & $\begin{array}{l}\text { - ensuring access to attractive teaching resources } \\
\text { and toys, } \\
\text { - increasing the number of radio and television } \\
\text { programmes that include ecological content }\end{array}$ \\
\hline II & $\begin{array}{l}\text { Primary } \\
\text { and secondary } \\
\text { schools }\end{array}$ & $\begin{array}{l}\text { 1. Shaping a person aware of their unity with the natural } \\
\text { and sociocultural environment. } \\
\text { 2. Developing skills to observe the environment and } \\
\text { collect information about it. } \\
\text { 3. Building respect for life and health of both one's own } \\
\text { and all other beings. } \\
\text { 4. Implementing active forms of education in the field, e.g. } \\
\text { nature schools. } \\
\text { 5. Establishing cooperation between teachers in order } \\
\text { to create an atmosphere good for the execution } \\
\text { of fundamental objectives of ecological education }\end{array}$ & $\begin{array}{l}\text { - initiating and attending national and internationa } \\
\text { environmental education programmes, } \\
\text { - constantly undertaking and expanding activities } \\
\text { for environmental protection in schools and their } \\
\text { surroundings, } \\
\text { - highlighting a positive role of children in } \\
\text { environmental education of adults, } \\
\text { - carrying out environmental education in the field }\end{array}$ \\
\hline III & Higher education & $\begin{array}{l}\text { 1. Preparing specialists for professional work regarding } \\
\text { environmental protection. } \\
\text { 2. Organizing postgraduate studies which supplement } \\
\text { knowledge of environmental protection. } \\
\text { 3. Giving unofficial environmental education by organizing } \\
\text { open universities and lectures }\end{array}$ & $\begin{array}{l}\text { Universities should be places where postgraduate } \\
\text { studies and courses for teachers, administrative } \\
\text { officers or journalists are organized. } \\
\text { Universities should publish and promote textbooks } \\
\text { and scripts dealing with the issue of environmental } \\
\text { protection in a broad sense }\end{array}$ \\
\hline
\end{tabular}

Source: own work on the basis of: National Strategy... (2001), p. 8.

It can be observed that in the recent years there has been a growing interest among adults in acquiring ecological knowledge as part of the official and unofficial education system. The role of open universities, postgraduate studies, courses, training as well as attractive forms of promoting knowledge such as competitions, promotions, exhibitions or workshops is increasing. A significant part in developing environmental education among adults should be played by local authority structures. 
Education for sustainable development aims at educating society. In terms of that, activities of entities providing education services (schools, organizations, entrepreneurs, associations) should mainly develop attitudes and behaviours of society, promote historical values and tradition, and emphasise the significance of interpersonal cooperation. They should also promote nature, the beauty of landscapes and communing with nature as well as highlight an important role of corporate social responsibility ${ }^{4}$ which is the answer to the concept of sustainable development.

Apart from giving knowledge and creating values, education for sustainable development should teach ethics, good practices and, above all, present the hierarchy of values which includes the concept of sustainable development.

\section{Method}

The following exploration methods and techniques were used in the research process: desk research analysis, critical analysis of national and foreign literature on the subject, questionnaire interview (standardized). The research was conducted among students of the University of Szczecin studying Finance and Accounting. The results of the research allowed to formulate conclusions and recommendations. Students of the following programmes took part in the research:

\section{Full-time BA programme.}

2. Full-time MA programme.

In total, there are 150 students of Finance and Accounting in the academic year 2017/2018 at the University of Szczecin. Whereas 94 students, that is $63 \%$ of all students, participated in the research titled "Sustainable development - students' ecological awareness". The research was conducted in October 2017.

\section{Resulls}

Education on sustainable development is understood as a process shaping the full scope of relations between a human, society and the natural environment. Its task is to change individuals' attitudes towards the environment. In accordance with international and Polish programme documents, it should be present during the whole education process and include all social groups. The effect of ecological education is the acquired knowledge. The final goal of ecological education is to increase ecological awareness and responsibility for the environment as well as undertake activities contributing to minimizing the negative impact on the natural environment.

The research findings are as follows:

1. Only $35.17 \%$ of respondents know a correct definition of sustainable development.

2. $20 \%$ of respondents indicated that the majority of problems connected with pollution and degradation of the environment in their places of living concern poor waste management and destruction of valuable natural areas (e.g. through development, deforestation, changes in the water system).

3. According to $90 \%$ of respondents, an average citizen is responsible for the condition of the natural environment.

${ }^{4}$ The idea of corporate social responsibility is a view on social and environmental issues which is still optional, but exceeds the applicable legal requirements that business entities take account of more: Ignatowski, Wójcik-Jurkiewicz (2016), p. 127. 
4. Local authorities, commune's residents and local entrepreneurs were deemed by respondents most important entities which should undertake activities that would improve the condition of the environment.

5. $41 \%$ of respondents were not rather ready to pay an additional, voluntary tax in order to protect the environment.

6. As many as $23 \%$ of the research participants have not recently tried to reduce energy, water and gas consumption.

7. $67 \%$ of respondents confirm that in their households there is municipal waste sorting.

8. As many as $60 \%$ of students participating in the research use reusable bags while shopping.

9. $10 \%$ of the research participants never voluntarily resign from using cars in order to use public transport.

10. Main motives for undertaking activities contributing to the protection of the natural environment by students are respect for nature and economic reasons.

11. $70 \%$ of respondents have never participated in promotional, educational or training activities aimed at providing knowledge of sustainable development.

12. When assessing the effectiveness of activities of local authorities concerning environmental protection, students taking part in the research claimed that activities of a commune are unsatisfactory $37 \%$ of respondents) and in terms of activities of a district as many as $41 \%$ of respondents are not able to assess them.

13. $53.19 \%$ of respondents think that public sector entities such as: Housing Management Department, Water and Sewage Company, Bus Services Company, Forest District, do not undertake any activities for sustainable development.

14. Only $35 \%$ of the students participated in the past in promotional, educational or training activities aimed at providing knowledge of sustainable development, mainly in terms of forest education.

\section{Conclusions}

1. Education for sustainable environment is an element of a human life and plays a significant role in it.

2. Humans have always been connected with the environment - nature has given them everything they have needed to survive and, at the beginning, education was more of a tale, a fable or a story.

3. The society often gets education for sustainable development for free.

4. All citizens can take advantage of ecological education if they want, no potential user is excluded from access to education and citizens do not pay for education directly.

5. Environmental (ecological) education contributes to creating attitudes of young generations and to a better understanding of sustainable management.

6. The objective of education for sustainable development is to teach the society - create attitudes and social behaviours, promote historical values and traditions as well as emphasise the significance of cooperation between people. Education aims at promoting nature, the beauty of landscapes, communing with nature and highlighting an important role of corporate social responsibility.

7. The level of knowledge of the students of Finance and Accounting is not satisfactory.

8. Students do not often participate in the organized classes and despite awareness of the significance of sustainable development they would not be always willing to support such development (voluntary taxes). 
9. As a result of the conducted research, it can be claimed that the formulated hypothesis: "Long-term educational programmes executed as part of the education system and activities of enterprises, organizations, foundations or associations considerably contribute to developing a high level of natural and ecological awareness of the young generation" has not been positively verified, which means that public organizations, schools, business entities as well as the society itself still have to do a lot in order to promote knowledge of the role and significance of natural resources.

\section{Referenences}

Borys, T. (2010). Dekada edukacji dla zrównoważonego rozwoju - polskie wyzwania. Problemy Ekorozwoju, 10, 64.

Hauff, V. (ed.) (1987). Unsere gemeinsame Zukunf - der brundtland- bericht der weltkommission fur Umwelt und Entwicklung. Greven, p. 46 (original title: World Commission on Environment and Development: Our common future).

http://www.gridw.pl/cele-zrownowazonego-rozwoju (1.10.2017).

Ignatowski, R., Wójcik-Jurkiewicz, M. (2016). Raportowanie spółek w zakresie społecznie odpowiedzialnego biznesu. In: G. Ignatowski, Ł. Sułkowski, Z. Dobrowolski (eds.), Instrumenty polityki społecznej. Warszawa: Difin.

Kogut-Jaworska, M. (2018). Financing of regional and local development by the territorial self-government units in Poland within the EU Cohesion Policies In: P. Jedlička, P. Marešová, I. Soukal (eds.), Hradec Economic Days: double-blind peer-reviewed proceedings of the international scientific conference Hradec Economic Days 2018, January 30-31, 2018. Part 1, vol. 8 (pp. 411-415). Hradec Králové, Czech Republic.

Lorek, E., Sobol, A. (2010). Edukacja na rzecz zrównoważonego rozwoju - działania Uniwersytetu Ekonomicznego w Katowicach. In: B. Kos (ed.), Ekonomia jako obszar badań naukowych - trendy, perspektywy rozwoju. Katowice: Publishing House of the University of Economics in Katowice.

Luks, F. (2002). Nachhaltigkeit. Hamburg.

National Strategy for Ecological Education - through education to sustainable development. Ministry of the Environment (2001). Retrieved from: https://www.mos.gov.pl (1-2.10.2017).

Pionek, B. (2002). Koncepcja rozwoju zrównoważonego i trwałego Polski. Warszawa: Wydawnictwo Naukowe PWN.

Radke, V. (2001). Indikatoren der Nachhaltigkeit - Bedingungen der empirischen Messung des Konzepts. In: M. Held, H. Nutzinger (eds.), Nachhaltiges Naturkapital, Ökonomik und zukunftsfähige Entwicklung. Frankfurt a. M.

Rogall, H. (2010). Ekonomia zrównoważonego rozwoju Teoria i praktyka. Poznań: Zysk i S-ka.

Sadowska, B. (2016). Strategia Państwowego Gospodarstwa Leśnego Lasy Państwowe, a zrównoważony rozwój. Research Papers of Wrocław University of Economics, 437, 394-396.

Woś, A. (1992). Rolnictwo zrównoważone. Zagadnienia Ekonomiki Rolnej, 1-3.

Wójcik-Jurkiewicz, M. (2016). Idea społecznie odpowiedzialnego biznesu a kształtowanie wyniku finansowego spółki. Studia Ekonomiczne. Zeszyty Naukowe Uniwersytetu Ekonomicznego in Katowice, 253, 141.

Cite this article aS: Sadowska, B. (2018). Significance of Education for the Economy of Sustainable Development - Toward Social Responsibility. European Journal of Service Management, 3 (27/1), 247-254. DOI: 10.18276/ejsm.2018.27/1-31. 